\title{
JENIS-JENIS KIMA DAN KELIMPAHANNYA DI PERAIRAN AMDUI DISTRIK BATANTA SELATAN KABUPATEN RAJA AMPAT
}

\author{
Giant clam species and abundancy in Amdui \\ District of South Batanta, Raja Ampat
}

\author{
Absalom Wakum ${ }^{1}$, Muhammad Takdir ${ }^{*}$, Selfanie Talakua ${ }^{1}$ \\ ${ }^{1}$ Jurusan Perikanan, FPIK UNIPA, Manokwari, 98314, Indonesia \\ *Korespondensi: moehtakdir@gmail.com
}

\begin{abstract}
ABSTRAK
Kima merupakan salah satu jenis molusca laut yang banyak ditemukan di perairan Raja Ampat. Hewan ini dilindungi di seluruh dunia termasuk di Indonesia. Penelitian ini dilakukan pada bulan Maret-April 2014, di perairan Amdui yang memiliki ekosistem terumbu karang dan ditetapkan 3 lokasi pengamatan yaitu: Pulau Ayem, Teluk Sawawris dan Teluk Sawros. Metode yang digunakan pada penelitian ini adalah metode observasi dengan teknik belt transek, dan bertujuan untuk mengetahui jenis dan kelimpahan kima di perairan Amdui. Kima yang ditemukan di perairan laut Kampung Amdui Kabupaten Raja Ampat yaitu 8 jenis terdiri dari T. crocea, T. maxima, T. squamosa, T gigas, H. Porcellanus, H. hippopus, T. tevoroa dan T.derasa. Kelimpahan relatif kima pada stasiun I tertinggi didominasi oleh jenis T. maxima dengan persentase $48.387 \%$ dengan kelimpahan relatif terendah pada jenis T.squamosa dengan persentase $3.225 \%$ dan kepadatan terendah pada jenis T.squamosa dengan persentase 0.002 individu $/ \mathrm{m}^{2}$.. Kelimpahan relative kima tertinggi pada stasiun II didominasi oleh jenis T. maxima yaitu $38.805 \%$ dan kelimpahan relative terendah pada jenis T. squamosa adalah $2.985 \%$. Kepadatan terendah adalah 0.004 individu $/ \mathrm{m}^{2}$ pada jenis T.maxima.Sedangkan kepadatan tertinggi pada jenis T. maxima adalah 0.052 terdapat pada stasiun II. Kelimpahan relative kima tertinggi pada stasiun III didominasi oleh jenis T.crocea yaitu $139.860 \%$, dan dengan kelimpahan relative terendah pada jenis T.tevoroa adalah $0.699 \%$ dengan kepadatan kepadatan tertinggi pada jenis T.crocea adalah 0.112 individu $/ \mathrm{m}^{2}$.
\end{abstract}

Kata kunci: kima, perairan Amdui, Raja Ampat, kelimpahan

\begin{abstract}
Giant clams, fauna that wellknown protected worldwide were also found in Raja Ampat. This study aimed to inventarus the giant clam species and its abundancy, and was done on March-April 2014 in Amdui that has coral reef ecosystem. Three sites study were in Ayem isle, Sawaris Bay and Sawros Bay, and the method used observation and belt transect technique. Giant clams found consisted 8 species that were T. crocea, T. maxima, T. squamosa, $T$.gigas, $H$. porcellanus, $H$. hippopus, $T$. tevoroa dan T.derasa. The highest abundancy of giant clams was in station I dominated by T. maxima with percentage 48.387 $\%$, and then the lowest abundancy was T.squamosa (3.225\%) also the density of T.squamosa only 0.002 individu/ $\mathrm{m}^{2}$. At station II, the highest abundancy was T. maxima $(38.805 \%)$ and the lowest T. squamosa $2.985 \%$. The density however, ranged from T.maxima 0.004 to 0.052 individu $/ \mathrm{m}^{2}$. At station III, T.crocea dominantly covered at $139.860 \%$, and the lowest abundancy was T.tevoroa $0.699 \%$, and the highest density was T.crocea 0.112 individu $/ \mathrm{m}^{2}$.
\end{abstract}

Key words: giant clam. Amdui, Raja Ampat, abundancy 


\section{PENDAHULUAN}

Kabupaten Raja Ampat merupakan salah satu wilayah kepulauan yang terdiri dari kurang lebih 610 buah pulau besar dan kecil, terbentang dengan luas sekitar 4,6 juta hektar. Kabupaten ini memiliki sumberdaya hayati laut berupa terumbu karang, hutan bakau, padang lamun dan aneka sumberdaya ikan. Terumbu karang memiliki nilai yang sangat penting bagi ekosisitem dan lingkungan di wilayah pesisir kepulauan Raja Ampat karena terletak pada wilayah segitiga terumbu karang yang terbentuk diantara Filiphina, Seme-nanjung Malaya, dan New Guinea (Coremap II, 2006). Kawasan terumbu karang Raja Ampat dihuni oleh 1074 jenis ikan karang dan 665 spesies moluska (Anonim, 2005).

Kima merupakan salah satu jenis molusca laut yang banyak ditemukan di perairan Raja Ampat. Hewan ini dilindungi di seluruh dunia termasuk di Indonesia. Pada tahun 1987 pemerintah Indonesia melalui Surat Keputusan Menteri Kehutanan No. 12/Kpts/II/1987 yang diperkuat dengan Pera-turan Pemerintah No. 7 Tahun 1999 memasukkan ketujuh jenis kima yang hidup di Indonesia menjadi hewan yang dilindungi. Penetapan tersebut berdasarkan kenyataan bahwa populasi kima di alam sudah sangat menurun terutama disebabkan oleh pemanfaatan manusia. Secara tradisional hewan ini dimanfaatkan oleh penduduk di sekitar pantai yaitu sebagaibahan makanan, bahan bangunan, bahan souvenir maupun sebagai hewan akuarium (Efendi, 2009). Dewasa ini kima dikenal sebagai salah satu hewan akuarium yang sangat menarik dan merupakan komoditi eksport yang sangat penting dari berbagai negara.

Pemanfaatan hewan ini di beberapa tempat masih tetap berlangsung. Hal ini bisa dilihat di wilayah pesisir dimana masih banyak ditemukan cangkang-cangkang (shells) kima yang menumpuk di rumah-rumah penduduk untuk digunakan sebagi bahan bangunan (Anonimous, 2011), bahkan hingga saat ini masih bisa ditemukan daging kima segar yang dijual di pasar tradisional. Karena pemanfaatan tersebut yang masih tetap berlangsung dan harganya yang sangat tinggi di luar negeri dikhawatirkan mengakibatkan eksploitasi yang berlebih (over exploitation). Chandika (2007) menyatakan bahwa populasi kima di alam menurun sangat drastis diseluruh duniaakibat eksploitasi yang berlebihan. Kondisi seperti ini dapat saja terjadi pada potensi sumberdaya kima di perairan Kampung Amdui Kepulauan Raja Ampat.

Guna mengatur keseimbangan populasi kima di alam dan untuk tujuan pemanfaatan secara berkelanjutan maka sangat dibutuhkan informasi tentang keberadaan kima di perairan Amdui. Atas dasar tersebut maka dilakukan penelitian untuk mengetahui bagaimana kelimpahan jenis dari kima yang ada khususnya di perairan Amdui.

\section{METODE PENELITIAN}

\section{Tempat dan Waktu}

Penelitian dilakukan pada bulan Maret-April 2014, pada perairan Amdui yang memi-liki ekosistem terumbu karang. Pada daerah tersebut ditetapkan 3 lokasi penga-matan yaitu: Pulau Ayem, Teluk Sawawris dan Teluk Sawros. Penelitian ini dilakukan pada tiga (3) stasiun yang berada di perairan Amdui yaitu perairan Pulau Ayem (stasiun I) dengan posi-si geografis S00 $49^{\prime} 18,8^{\prime \prime}$ dan E130 $54^{\prime} 05,6^{\prime}$ ' perairan Teluk Sawawris (satsiun II) dengan posisi geografis, $\mathrm{S} 00^{\circ} 46^{\prime} 33,2^{\prime}$ ' dan E 130 55,08 ,1' 'dan periran Teluk Sauros (Stasiun III) dengan posisi geografis, $\mathrm{S} 00^{\circ} 47^{\prime} 18,1^{\prime \prime}$ dan E $130^{\circ} 50^{\prime}$ 58,1 '. Perairan pu-lau Ayem dan perairan teluk Sawawris adalah kedua dari pulau yang berdekatan, sedangkan stasiun III jauh dari pemukiman masyarakat sehingga ekosistem tersebut terjaga ya-itu ekosisitem terumbu karang, ekosisitem mangrove, ekosisitem lamun dan ekosisitem estuary.

Alat dan bahan yang digunakan dalam Penelitian ini adalah: 
Tabel 1. Alat dan Kegunaan

\begin{tabular}{cll}
\hline No & \multicolumn{1}{c}{ Alat } & \multicolumn{1}{c}{ Kegunaan } \\
\hline 1 & GPS & Untuk menentukan posisi titik koordinat tiap-tiap stasium \\
2 & Kamera digital & Dokumentasi \\
3 & Alat tulis menulis & Mencatat hasil pengamatan \\
4 & Rool meter & Sebagai alat ukur \\
5 & Tali rafiah & Sebagi pembatas area plot \\
6 & pH meter & Mengukur pH air \\
7 & DO & Mengukur oksigen terlarut di perairan \\
8 & Refraktor meter & Mengukur salanitas \\
9 & Papan lapangan & Pengalas kertas untuk mencatat hasil pengamatan \\
10 & Snorkling & Untuk menyelam mengambil sampel \\
\hline
\end{tabular}

Tabel 2. Bahan dan Kegunaan

\begin{tabular}{cll}
\hline No & \multicolumn{1}{c}{ Bahan } & \multicolumn{1}{c}{ Kegunaan } \\
\hline 1. & Kima & Sampel yang akan diamati \\
2. & Buku identifikasi & Untuk mengidentifiksi jenis-jenis kima \\
\hline
\end{tabular}

\section{Metode Pengambilan Data}

Metode yang digunakan pada penelitian ini adalah metode observasi dengan teknik belt transek. Prosedur Kerja yang dilakukan adalah sebagai berikut:

1. Tarik garis transect sepanjang $100 \mathrm{~m}$ seja-jar lurus dengan garis pantai pada kedalam 3, 6, 9 m, sehingga tiap lokasi ada 3 garis transek,

2. Pengamatan dilakukan pada tiap $2,5 \mathrm{~m}$ di sebelah kanan dan kiri garis transect.

3. Semua kima yang ditemukan diidentifikasi dan dihitung jumlahnya serta diukur panjang, lebar cangkangnya dengan menggunakan mistar setelah itu di dokumen-tasikan.
4. Identifikasi kima dilakukan dengan melihat bentuk cangkang dan habitat dari jenis kima tersebut berdasarkan identifikasi jenis kima dengan mengacu pada buku identifikasi dalam Knop, (1996).

5. Dilakukan pengukuran kualitas air yang meliputi suhu, salinitas, $\mathrm{pH}$, kandungan oksigen, dan kecerahan.

6. Selain metode observasi digunakan metode koleksi bebas, apabila pada lokasi ter-sebut tidak mendapatkan jenis-jenis kima pada daerah pengamatan maka kami menggunakan koleksi bebas di luar daerah pengamatan dalam penggunaan metode ini sampel diamati dengan cara snorkling.

\section{Ekosistem terumbu karang}

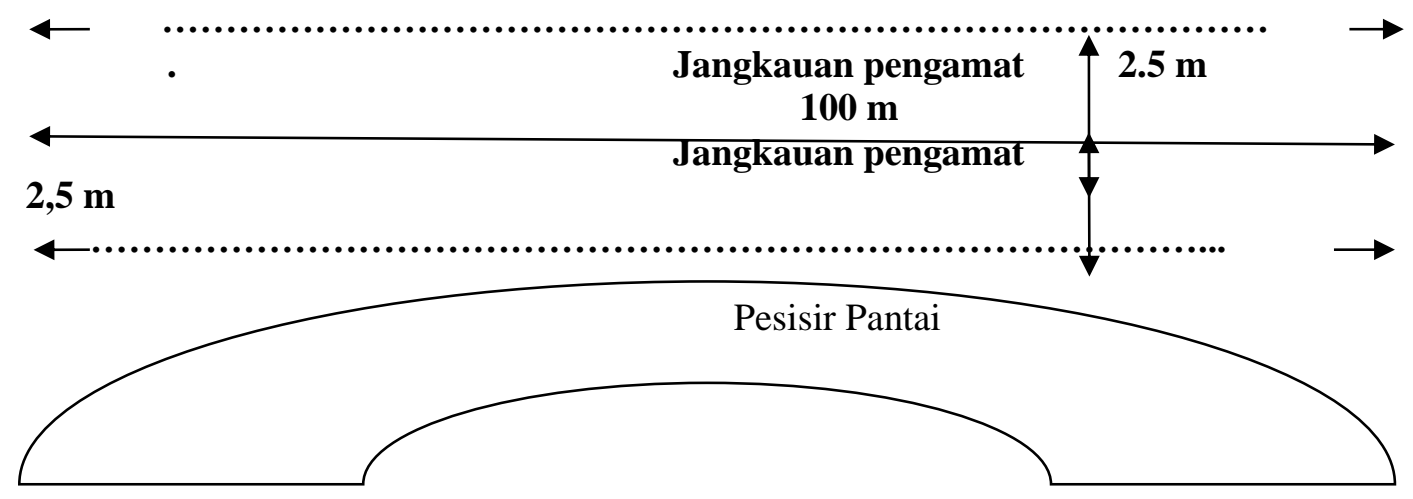

Gambar 1. Sketsa pengembilan sampel dengan metode belt transect. 


\section{Analisis Data}

Analisis data untuk menghitung kelim-pahan kima dan kepadatan kima di lokasi penelitian dengan menggunakan rumus Ke-limpahan Relatif dan Kepadatan.

\section{Kelimpahan Relatif}

Kelimpahan kima yang dianalisis seba-gai kelimpahan relatif yaitu jumlah individu per total individu yang menempati, suatu area pengamatan atau suatu habitat (Fachrul, 2007 ), untuk rumus kelimpahan relatif (KR) yaitu :

$\mathrm{KR}=(\mathrm{ni} / \mathrm{N}) \times 100 \%$

Keterangan :

$\mathrm{KR}=$ Kelimpahan relatif spesies

$\mathrm{ni}=$ Jumlah individu spesies-i

$\mathrm{N}=$ Jumlah total individu

\section{Kepadatan}

Kepadatan yang ditemukan pada disetiap lokasi pengamatan perhitungannya menggu-nakan rumus yang di- kembangkan oleh (Krebs, 1989 dalam Wyser, 2011).

$$
=\frac{\begin{array}{l}
\text { Kepadatan } \\
\text { Jumlah individu tiap spesies }
\end{array}}{\text { Luas area sampling }}
$$

\section{HASIL DAN PEMBAHASAN}

Penelitian ini dilaksanakan di perairan Amdui. Distrik Batanta Selatan Kabupaten Raja Ampat Provinsi Papua Barat. Batanta merupakan salah satu dari 4 pulau besar di kepulauan Raja Ampat meliputi wilayah seluas, $453 \mathrm{~km} .^{2}$. Perairan kampung Amdui memiliki parameter kualitas fisik-kimia pe-rairan yang baik. Kualitas air di Amdui memiliki kisaran suhu $30{ }^{\circ} \mathrm{C}$ sampai $32{ }^{\circ} \mathrm{C}$, salinitas $34 \%$, pH 7 , dan oksigen terlarut 9,66 sampai 3,66 (Tabel 3) dengan beberapa ekosistem yaitu terumbu karang, mangrove dan lamun yang memiliki keanekaragaman biota yang tinggi, diantaranya kima.

Tabel 3. Parameter Kualitas Air di Lokasi Penelitian

\begin{tabular}{llccc}
\hline \multirow{2}{*}{ No. } & \multirow{2}{*}{ Parameter } & \multicolumn{3}{c}{ Stasiun } \\
\cline { 3 - 5 } & & Pulau Ayem & T. Sawawris & T. Sauros \\
\hline 1. & Salinitas $(\% 0)$ & 34 & 34 & 34 \\
2. & Suhu $\left({ }^{\circ} \mathrm{C}\right)$ & 32 & 30 & 32 \\
3. & Oksigen Terlarut & 9,66 & 6,45 & 6,33 \\
4. & $\mathrm{pH}$ & 7 & 7 & 7 \\
\hline
\end{tabular}

Pengukuran salinitas dilakukan pada saat siang hari dimana salinitas air pada ketiga stasiun pengamatan adalah sama yaitu $34 \%$. Salinitas merupakan salah satu parameter yang mempengaruhi penyebaran hewan bentos seperti bivalvia. Hasil penelitian Harahap dalam Candhika, (2007) mengemukakan bahwa Salinitas optimum untuk pertumbuhan kima adalah 30-32\%. Suhu perairan Amdui berkisar antara $30^{\circ} \mathrm{C}-32^{\circ} \mathrm{C}$. Nilai kisaran ini tergolong baik untuk pertumbuhan kima. Kandungan oksigen terlarut pada lokasi penelitian yaitu berkisar 6,3-9,6 ppm, tergolong baik untuk pertumbuhan kima dan biota lainnya. Rata-rata $\mathrm{pH}$ adalah 7 ppm dan cenderung basa. Nilai keasaman sangat mempengaruhi proses biokimiawi perairan, derajat keasaman dipengaruhi oleh dekom-posisi tanah dan dasar perairan serta keadaan lingkungan sekitarnya. Sebagian biota akuatik sensitif terhadap perubahan $\mathrm{pH}$ dan menyukai nilai pH sekitar 6-7,8 (Effendi, 2000).

\section{Jenis-Jenis Kima yang Ditemukan}

Jenis-jenis kima yang ditemukan pada lokasi penelitian sebanyak 8 spesies yaitu Tridachna gigas, T. maxima, $T$. 
derasa, T. tevoroa, T. crocea, T. porcellanus. Jenis-jenis kima ini memiliki squamosa, Hippopus hippopus, dan $H$. namalokal seperti terlihat pada Tabel 4.

Tabel 4. Jenis Kima yang ditemukan dan Nama lokalnya

\begin{tabular}{|c|c|c|c|c|}
\hline \multirow[t]{2}{*}{ Genus } & \multicolumn{4}{|c|}{ Spsecies } \\
\hline & Latin & Lokal & Indonesia & Internasional \\
\hline \multirow{3}{*}{ Tridacnidae } & T. Crocea & Intef & Kima besar & Crocea Clam \\
\hline & T. maxima & Inkonsonsen & Kima besar & Maxima Clam \\
\hline & T. squamosa & Irpur & Kima sisik & $\begin{array}{l}\text { Scaly,Fluted } \\
\text { giant clam }\end{array}$ \\
\hline \multirow{5}{*}{ Hippopus } & T. gigas & Intef & Kima Raksasa & Giant Clam \\
\hline & H. porcellannus & Mangkapdu & - & - \\
\hline & T. tevoroa & Syau & - & - \\
\hline & H. hippopus & Katop Arpos & $\begin{array}{c}\text { Kima Tapak } \\
\text { Kuda }\end{array}$ & - \\
\hline & T. derasa & Mangkapdu & & - \\
\hline
\end{tabular}

\section{Komposisi Kima yang ditemukan}

Komposisi kima yang ditemukan berbeda pada masing-masing stasiun pengamatan. Jenis $T$. crocea, T. maxima, T. squamosa, T. gigas, dan H. hippopus ditemukan pada ketiga stasiun dengan jumlah yang berbeda-beda sedangkan jenis $T$. derasa, T. tevoroa hanya dite- mukan pada stasiun III dan jenis $\mathrm{H}$. porcellanus hanya ditemukan pada stasiun II dan III. Perbedaan komposisi jenis dari masing-masing stasiun diduga karena perbedaan kondisi habitat dan tingkat pemanfaatan oleh masyarakat. Komposisi kima per stasiun dapat dilihat pada Tabel 5.

Tabel 5. Komposisi Kima Per Stasiun

\begin{tabular}{clcccc}
\hline \multirow{2}{*}{ No. } & \multirow{2}{*}{ Jenis Kima } & \multicolumn{3}{c}{ Jumlah Individu Per Stasiun } & \multirow{2}{*}{ Total } \\
\hline 1 & T.crocea & 8 & 14 & 56 & 78 \\
2 & H.hippopus & 4 & 14 & 27 & 45 \\
3 & T. gigas & 3 & 8 & 3 & 14 \\
4 & H. porcellanus & 0 & 3 & 11 & 14 \\
5 & T. squamosal & 1 & 2 & 19 & 22 \\
6 & T. maxima & 15 & 26 & 20 & 61 \\
7 & T. derasa & 0 & 0 & 6 & 6 \\
8 & T. tevoroa & 0 & 0 & 1 & 1 \\
& Total & $\mathbf{3 1}$ & $\mathbf{6 7}$ & $\mathbf{1 4 3}$ & $\mathbf{2 4 1}$ \\
\hline
\end{tabular}

Jenis kima terbanyak untuk ketiga stasiun adalah T. crocea dan T. maxima. Sedangkan yang paling sedikit jumlahnya adalah Kima T. tevoroa. Menurut (Pasaribu, 1988, dan Taniera, 1988) bahwa menurunnya populasi kima di alam, antara lain di sebabkan oleh pengambilan atau pemanenan kima secara langsung di alam karena terdorong oleh kebutuhan pendu- duk disekitar pantai. Hal serupa diduga terjadi pada lokasi penelitian ini. Stasiun III memiliki jumlah spesies dan jumlah individu per spesies yang paling banyak di-banding pada dua stasiun pengamatan lainnya karena diduga tingkat pengambilannya oleh masyarakat lebih sedikit. Hal ini terjadi karena lokasi tersebut jauh dari aktifitas ma-syarakat setempat yang 
berada di bagian pesisir Raja Ampat yang tinggal di perairan Amdui. Sementara jumlah spesies dan jumlah individu yang paling sedikit di-temukan pada stasiun I yang merupakan lokasi dimana masyarakat mela-kukan aktivitas kegiatan penangkapan. Demikian halnya pada stasiun II yang lokasinya tidak terlalu jauh untuk dijangkau oleh masyarakat. Perbandingan jumlah individu kima per stasiun tertera pada Gambar 6.

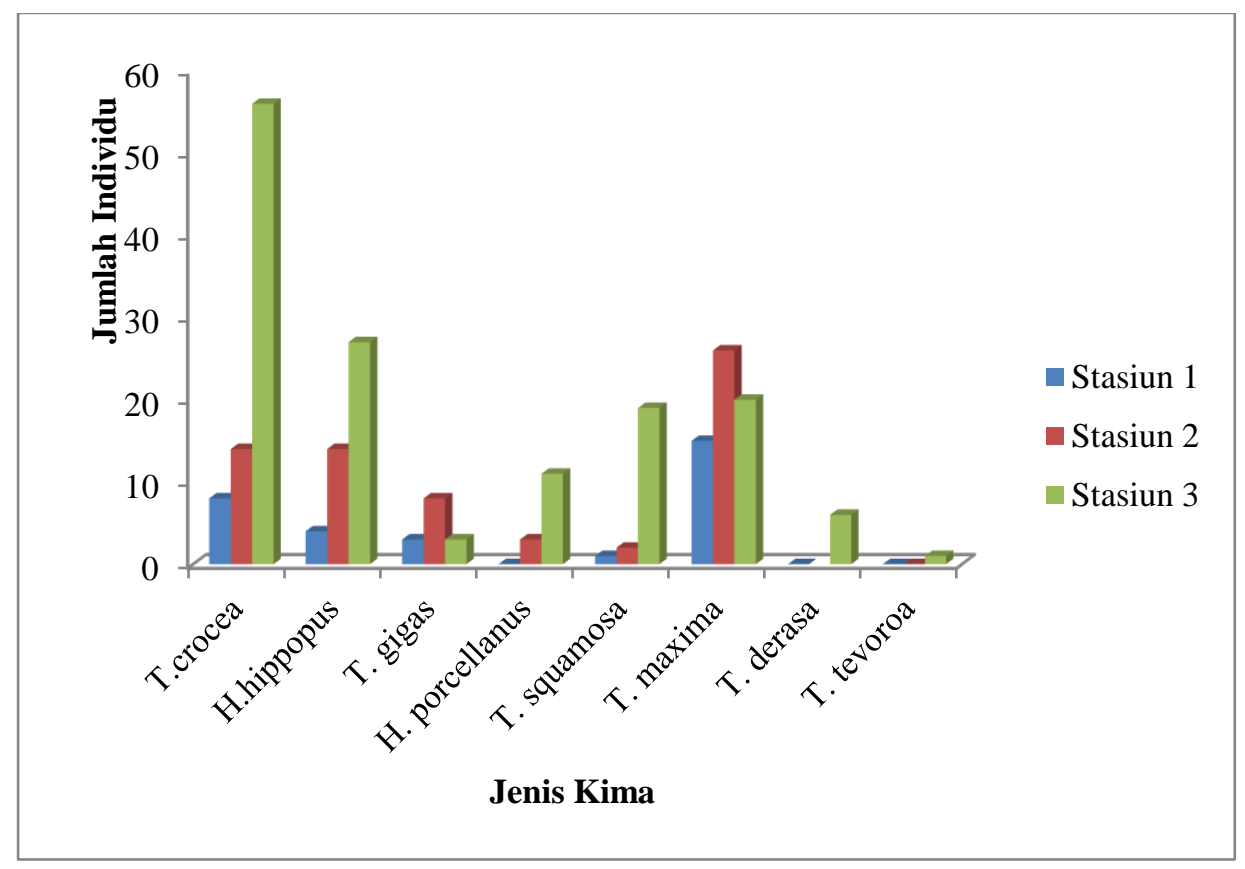

Gambar 6. Grafik perbandingan jumlah individu kima per stasium

\section{Kelimpahan Relatif}

Kelimpahan relatif kima merupakan indikasi melimpahnya jenis-jenis tertentu disuatu lokasi perairan. Data mengenai kelimpahan relatif dari ke-8 spesies kima yang ditemukan pada lokasi penelitian, dapat dilihat pada Tabel 6 .

Kelimpahan kima dimasing-masing stasiun, T. maxima merupakan jenis yang memiliki nilai persentase kelimpahan paling tinggi di ketiga stasiun yaitu 48,387\% di stasiun I (P. Ayem) , 38.805 $\%$ di stasiun II (T. Sawawris) dan $13.986 \%$ (T. Sauros). Jenis T. maxima lebih melimpah diban-dingkan jeni kima lainnya karena masyarakat kurang memanfaatkan jenis tersebut. Bebe-rapa jenis kima yang diketemukan pada $T$. Sauros tapi tidak pada P. Ayem dan T. Sawawris yaitu jenis $T$. derasa dan $T$. tevoroa. Hal ini diduga karena masyarakat sering mengambil jenis ini untuk dikonsumsi maupun untuk dijual. Selain itu, kedua lokasi tersebut dekat dengan daerah pemukiman masyarakat sehingga masyarakat lebih berpeluang untuk mengambil pada lokasi tersebut.

\section{Perbandingan kelimpahan kima dibeberapa tempat}

Faktor kondisi yang mempengaruhi kehi-dupan kima yaitu faktor ekologi antara lain : Suhu, Salinitas, pH dan kandungan oksigen terlarut serta adanya gangguan dari manusia. Jumlah spesies kima yang dite-mukan di perairan Amdui lebih banyak dibanding yang dilaporkan pada perairan lainnya yaitu 7 spesis pada perairan Teluk Doreri (Iriansyah, 2010) dan 5 spesies pada perairan Pulau Room (Alvanitha, 2012). Spesies kima T. crocea yang melimpah pada perairan Amdui juga dilaporkan melimpah pada perairan Pulau Room. Hal tersebut terjadi karena $T$. Crocea kurang diminati oleh masyarakat sebab jenis ini hidupnya menempel pada terumbu karang sehingga sulit untuk diambil (Alvanitha, 2012). Sementara T. gigas merupakan spesies yang paling 
sedikit jumlahnya pada hampir semua perairan yang telah dilaporkan. Hal tersebut terjadi karena spesies ini mudah diambil dari perairan dan memiliki harga jual yang tinggi sehingga banyak diminati.

Tabel 6. Kelimpahan relatif (\%) individu kima per stasiun.

\begin{tabular}{clccc}
\hline No. & \multicolumn{1}{c}{ Jenis Kima } & P. Ayem & Teluk Sawawris & T. Sauros \\
\hline 1 & T. crocea & 25.806 & 20.895 & 39.160 \\
2 & H. hippopus & 12.903 & 20.895 & 18.881 \\
3 & T. gigas & 9.677 & 11.940 & 20.979 \\
4 & H. porcellanus & 0 & 4.477 & 7.692 \\
5 & T. squmosa & 3.225 & 2.985 & 13.286 \\
6 & T. maxima & 48.387 & 38.805 & 13.986 \\
7 & T. derasa & 0 & 0 & 41.958 \\
8 & T. tevoroa & 0 & 0 & 0.699 \\
\hline
\end{tabular}

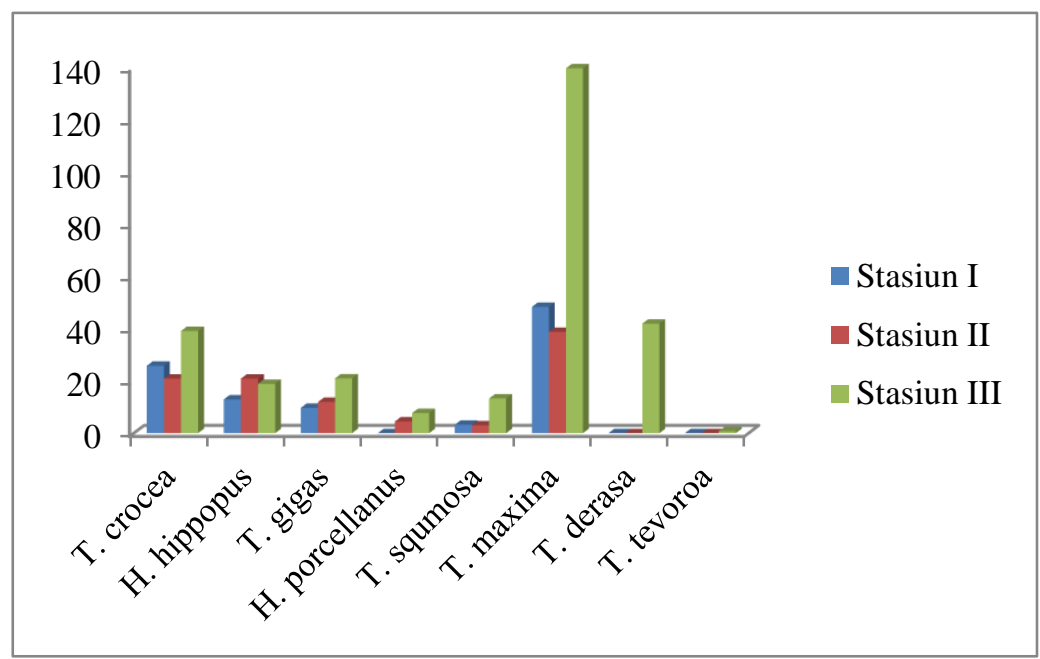

Gambar 7. Kelimpahan relatif jenis kima (\%) per stasiun

Tabel 7. perbandingan kelimpahan kima

\begin{tabular}{clccccc}
\hline & Perairan Amdui & \multicolumn{3}{c}{$\begin{array}{c}\text { Kepulauan } \\
\text { Roon }\end{array}$} & \multicolumn{3}{c}{ Teluk Doreri } \\
\hline NO & \multicolumn{1}{c}{ jenis kima } & Ket & \multicolumn{1}{c}{ Jenis kima } & Ket & jenis kima & Ket \\
\hline 1 & T. crocea & $\mathrm{M}$ & T. crocea & & T. crocea & $\mathrm{M}$ \\
2 & H. hippopus & $\mathrm{M}$ & H. hippopus & $\mathrm{K}$ & T. hipppus & $\mathrm{K}$ \\
3 & T. gigas & $\mathrm{M}$ & T. gigas & $\mathrm{K}$ & T. gigas & $\mathrm{K}$ \\
4 & H. porcellanus & $\mathrm{M}$ & H.porcellanus & $\mathrm{K}$ & H. porcelanus & $\mathrm{K}$ \\
5 & T. squmosa & $\mathrm{M}$ & T.squamosa & & T. squamosal & $\mathrm{K}$ \\
6 & T. maxima & $\mathrm{M}$ & T. maxima & & T. maxima & $\mathrm{K}$ \\
7 & T. derasa & $\mathrm{K}$ & & & T. derasa & $\mathrm{K}$ \\
8 & T. tevoroa & $\mathrm{K}$ & & & & \\
\hline
\end{tabular}

Sumber : Absalom Wakum. 2014 (Perairan Amdui); Henny Alvanitha Betay. 2012 (Kepulauan Roon) ; Iransyah.2010 (Teluk Doreri). Ket : M = Melimpah K = Kurang 


\section{Kepadatan Kima}

Nilai kepadatan kima dihitung berdasarkan jumlah individu yang dketemukan di setiap stasiun per luasan areal $500 \mathrm{~m}^{2}$. Kepa-datan kima pada perairan Amdui tertera pada Tabel 10. Berdasarkan tabel tersebut Nampak bahwa jenis yang memiliki kepa-datan tertinggi di stasiun I adalah jenis $T$. crocea dan $H$. hipopus, di stasiun II adalah jenis $H$. hippopus dan $T$. maxima, dan di stasiun III adalahT.crocea dan $H$. hippopus. Sedangkan jenis kima yang memiliki kepadatan terendah pada stasiun I, II, dan III adalah $T$. gigas, $H$. porcellanus, T. maxima.

Nugroho dan Ambariyanto (2001) me-ngemukakan bahwa pada umumnya hasil-hasil penelitian melaporkan bahwa populasi kima di alam didominasi oleh spesies-spesies kecil seperti Tridacna crocea dan Tridacna maxima, sedangkan spesies besar seperti Tri-dacna derasa, Tridacna squamosa, Hippopus hippopus dan Hippopusporcella-nus sudah sangat jarang ditemukan.

Pada gambar 8, dapat terlihat bahwa kepadatan tertinggi kima pada setiap stasiun, terdapat pada stasiun 3, yaitu jenis T. crocea. Kemudian diikuti oleh jenis $H$. hippopus, yang juga terdapat pada stasiun 3. Sedangkan pada stasiun 1 dan 2, kepadatan tertinggi adalah jenis $T$. maxima. Adapun jenis yang memiliki kepadatan terendah pada setiap stasiun, seperti jenis H. porcellanus, T. derasa, danT. tevoroa yang terdapat pada stasiun 1 dan jenis yang sama juga, yaitu $T$. tevoroa dan $\mathrm{T}$. derasa yang terdapat pada stasiun 2 . Tinggi rendahnya kepadatan jenis kima pada setiap stasiun, dikarenakan lokasi pengambilan sampel yang berbeda, substrat dan parameter perairan. Lokasi pengambilan sampel pada stasiun 1, terletak dekat dengan pemukiman masyarakat dan juga memiliki kondisi karang yang sudah rusak, sehingga kepadatan jenis kima yang terdapat pada stasiun ini tidak melimpah. Sedangkan pada stasiun 2, terdapat jenis kima dengan kepadatan yang sedang. Hal ini dikarenakan, stasiun 2 sedikit jauh dari pemukiman warga, sehingga faktor lingkungan masih mendukung kehidupan dari jenis-jenis kima. Stasiun 3, merupakan stasiun yang memilki kepadatan tertinggidari beberapa jenis-jenis kima yang diamati. Hal ini disebabkan karena stasiun ini terletak didaerah teluk dan jauh dari rumah warga, sehingga kondisi lingkungan perairan sangat mendukung kepadatan dari kima. Selain itu, kepadatan juga dipengaruhi oleh perbedaan jenis. Ada jenis-jenis yang bisa beradaptasi pada saat terjadinya perubahan linkungan, namun ada juga jenis yang sulit untuk beradaptasi, sehingga mempengaruhi kepadatan jenis pada setiap stasiun pengamatan.

Tabel 8. Kepadatan rata-rata individu kima per stasiun

\begin{tabular}{llccc}
\hline \multirow{2}{*}{ No. } & \multicolumn{1}{c}{ Jenis Kima } & \multicolumn{3}{c}{ Kepadatan } \\
\cline { 3 - 5 } & & P. Ayem & T. Sawawris & T. Sauros \\
\hline 1 & T.crocea & 0.016 & 0.028 & 0.112 \\
2 & H.hippopus & 0.008 & 0.028 & 0.054 \\
3 & T. gigas & 0.006 & 0.016 & 0.006 \\
4 & H. porcellanus & 0.000 & 0.006 & 0.022 \\
5 & T. squamosa & 0.002 & 0.004 & 0.038 \\
6 & T. maxima & 0.03 & 0.052 & 0.04 \\
7 & T. derasa & 0.000 & 0.000 & 0.012 \\
8 & T. tevoroa & 0.000 & 0.000 & 0.002 \\
\hline
\end{tabular}




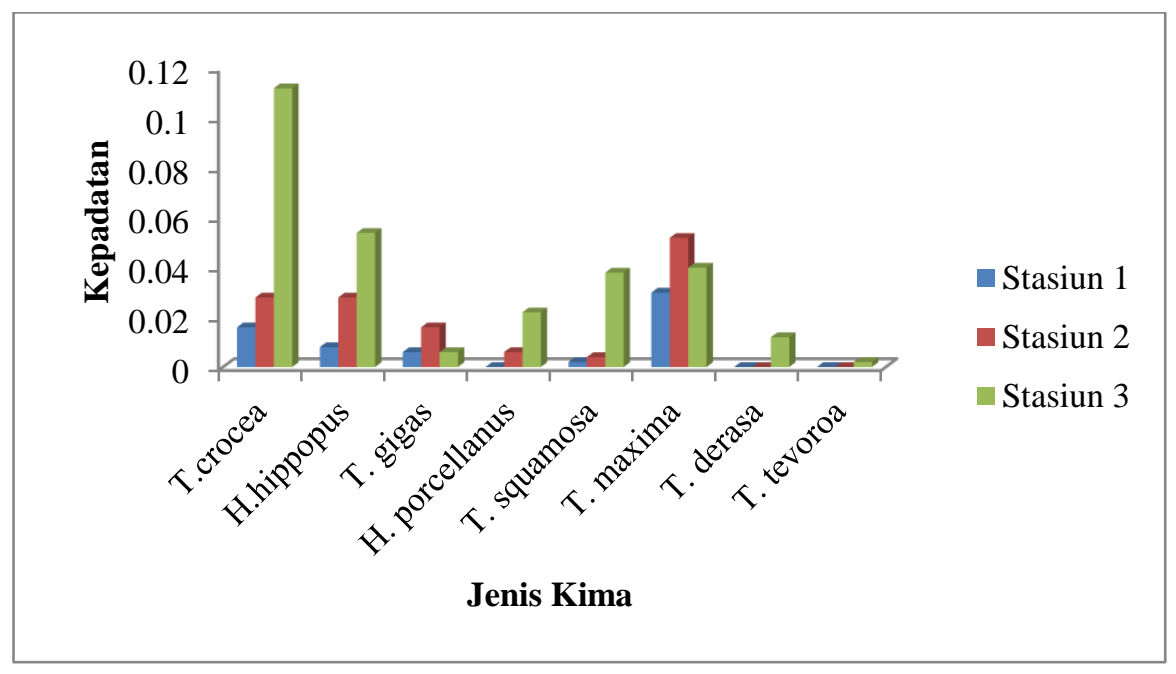

Gambar 8. Kisaran perbandingan kepadatan kima per stasiun

\section{KESIMPULAN}

Kima yang ditemukan di perairan laut Kampung Amdui Kabupaten Raja Ampat yaitu 8 jenis terdiri dari T. crocea, T. maxima, T. squamosa, T. gigas, $H$. porcellanus, H. hippopus, T. tevoroa dan T. derasa. Kelimpahan relatif kima tertinggi pada stasiun I yang didominasi oleh jenisT. maxima dengan persentase 48.387 $\%$ dengan kelimpahan relative terendah pada jenis $T$. squamosa dengan persentase $3.225 \%$ dan kepadatan terendah pada jenis $T$. squamosa dengan persentase 0.002 individu $/ \mathrm{m}^{2}$. Kelimpahan relative kima tertinggi pada stasiun II didominasi oleh jenis T. maxima yaitu $38.805 \%$ dan kelimpahan relative terendah pada jenis T. squamosa adalah $2.985 \%$. Kepadatan terendah adalah 0.004 individu $/ \mathrm{m}^{2}$ pada jenis T.maxima. Sedangkan kepadatan tertinggi pada jenis T. maxima adalah 0.052 terdapat pada stasiun II. Kelimpahan relative kima tertinggi pada stasiun III didominasi oleh jenis $T$. crocea yaitu $139.860 \%$, dan dengan kelimpahan relative terendah pada jenis $T$. tevoroa adalah $0.699 \%$ dengan kepadatan kepadatan tertinggi pada jenis T.crocea adalah 0.112 individu $/ \mathrm{m}^{2}$. Sedangkan kepadatan terendah adalah jenis $T$. tevoroa adalah 0.002 individu $/ \mathrm{m}^{2}$.

\section{DAFTAR PUSTAKA}

Dahuri, R., Rais, J., Ginting, S.P., and Sitepu.M.J. 1996.Pengelolaan Sumberdaya Pesisir dan Lautan Secara Terpadu (Integrated Coastal and Marine Resource Management). PT. Paradnya Paramita, Jakarta.

Galugu, M. B. 1997. Analisa Kualitas Lingkungan Perairan Teluk Jakarta Sehubung Dengan Pencemaran Bahan Organik. Skripsi. FPIK. Institut Pertanian Bogor

Koreleff, F., 1976.Determination of Phosphorus. Dalam : Methods of Seawatre Analysis (Grasshoff edt.). Verlag Chemi-Weinheim-New York : 117-126.

Menteri Negara Lingkungan Hidup. 2003. Keputusan Menteri Lingkungan Hidup No. 115 Tahun 2003 tentang Penetapan Status Mutu Air. Jakarta.

Menteri Negara Lingkungan Hidup RI, 2004. Keputusan Menteri Negara Lingkungan Hidup Nomor 51 Tahun 2004 tentang Baku Mutu Air Laut Untuk Biota Laut.

Nontji.A., 1994. Laut Nusantara. Penerbit Djambatan. Jakarta.

Palar, H. 1994.Pencemaran dan Toksikologi Logam Berat.Rineka cipta, Jakarta. 
